\title{
CHARLES MARTIN.
}

IT is with deep regret that we have to record the death of CHARLES MARTIN of Abergavenny who was killed in action on May 3rd, 1915, near Ypres.

Martin was educated at Eton. He had not, however, come out in his early days, and he appeared to his contemporaries only as a "modest, simpleminded, rather shy boy, and without the school accomplishments which make boy heroes." He found the lessons boring and got few good reports. Later on he went to Oxford and entered Magdalen College, the President of which was his mother's cousin, and, being a keen field naturalist, he selected Zoology as the subject most likely to interest him. After taking his degree he spent a summer with the Survey of the Freshwater Lochs of Scotland, and published observations on certain Oligochaets and Turbellaria found there. Subsequently he proceeded to the Zoological Station at Naples, and on his return made a brief stay at the Eustace Gurney Laboratory in Norfolk; he was then appointed Demonstrator of Zoology in the University of Glasgow. This post was relinquished in 1911, when he came south, and worked partly at Rothamsted, partly at the Lister Institute, and partly in his own laboratory at his home in Wales.

From the Turbellaria he passed to the Acinetaria, and then to the Protozoa on which most of his work was done. Most of his Papers were published in the Quarterly Journal of Microscopic Science; his last two, however, were in the Philosophical Transactions and in The Journal of Agricultural Science - both on Soil Protozoa.

The great characteristic of Martin's work was the freshness of his outlook. He never would be bound by tradition or convention, or even by time or circumstance. His work, therefore, was really original; he looked at the problem from a new point of view, attacked it in a new way, and always got an interesting result. This was well shown in his work at Rothamsted. He was at once attracted by the hypothesis that soil protozoa constitute one of the factors keeping down the bacterial numbers in the soil, and with characteristic enthusiasm he speedily struck a way through the experimental difficulties with which the subject bristled. He devised a method which for the first time demonstrated the presence of trophic amoebae in the soil and isolated and studied typical organisms present. His naturalist's instincts led him to make some very shrewd faunistic observations, which are being fully confirmed by later work. 
A mere discussion of Martin's work, interesting and valuable as it would be, is wholly inadequate to give any picture of what he was like in the Laboratory. In Martin's case you cannot separate the work from the man. While he was with us it was difficult to speak of him without affection, and now that he has gone it is impossible to think of him without emotion. Always boisterously cheerful, never serious, and yet always serious--for he would break off in the midst of the wildest chaff to plunge into the most truculent piece of laboratory work--always uncertain in the minor affairs of life, he was yet firm as a rock in all the things that really matter. You never knew when he would come, how long he would stay, or where he would go next, but you could always know that whether he was here or there he was always the same straight, honest man, free from any taint of unkindness or uncharitableness. And, whether his stay in the Laboratory was long or short, he would bring in a refreshing breeze from the open, and leave behind a wealth of illuminating suggestions.

He was that essentially British product, an amateur in science; a man possessed of private means, a good country house, considerable personal charm and social attainments, moving in a wide circle, and leading a great open life, who from among many possible paths chose that of science because he loved it. So long as we have such men British science can never be without the joy of the enthusiast, and can never degenerate into a mere trade. But just as he refused to be tied down by convention, so he refused to be tied down by science. At Oxford he had run the Magdalen beagles, and at home he was Master of the Crickhowell Harriers, besides fulfilling the other functions of the country gentleman. He had joined the O.T.C. at Glasgow, and when the war broke out went with the Monmouths. It was in the great battle early in May that he was killed by shrapnel while in charge of the machinegun section. We may be sure that he gave a good account of himself, and that he faced death as fearlessly as he had faced life. It was thus that he would have preferred to go; striking hard and doing something big: dying in defence of those ideals of honour amidst which he had always lived.

E. J. Russell. 